\title{
Effect of Storage Period on Wheat Grains Quality
}

\author{
El-Sisy $\mathrm{Tt}^{2 *}$, Abd El Fadel $\mathrm{Mg}^{1}$, Gad Ss ${ }^{1}$, El-Shibiny $\mathrm{Aa}^{1}$ and Emara $\mathrm{Mf}^{2}$ \\ ${ }^{1}$ Faculty of Environmental Agric. Sci. (Arish), Egypt \\ ${ }^{2}$ Regional Center for Food and Feed, Agriculture Research Center, Egypt \\ *Corresponding author: EL-Sisy TT, Faculty of Environmental Agric Sci (Arish), Egypt
}

\section{ARTICLE INFO}

Received: 幽 August 01, 2019

Published: 幽 August 12, 2019

Citation: Abdulrahman M Alhowikan, Fawzia AAl Rouq, Laila M Aldokhi, Hana Alzamil, Faten A Zakareia. Effect of Storage Period on Wheat Grains Quality. Biomed J Sci \& Tech Res 20(3)-2019. BJSTR. MS.ID.003461.

\begin{abstract}
The effect of storage period on mold and Aflatoxin production were investigated in wheat grains imported from Argentine, Germany, Ukrainian, Australia and U.S.A and Egyptian wheat grains (Gamaza 7). Moreover, the redaction the grade of wheat grains from grade (1) to grade (3), sample grade, insect infested and growth of Aspergillus flavus. Cylinders of milling are sources of increases fungal species pollution, total mould count and Aflatoxin production. The results suggest that must be use good storage for wheat grains and cleaning Cylinders before milling.
\end{abstract}

Keywords: Aspergillus; Aflatoxins; Storage; wheat; Flour; Physical; Chemical; Properties

\section{Introduction}

Unavoidable, natural contaminants in foods may have either chemical or biological origin. Mycotoxins, secondary metabolites of fungi are biological contaminants. Despite efforts to control fungal contamination, toxigenic fungi are ubiquitous in nature and occur regularly in worldwide food supplies due to mold infestation of susceptible agricultural products, such as grains, cereal, nuts, and fruits. Thousands of mycotoxins exist, but only a few represent significant food safety challenges. The natural fungal flora associated with foods is dominated by three genera Aspergillus, Fusarium, and Penicillium may include commensals as well as pathogens. The chemical structures of mycotoxins produced by these fungi are very diverse, as are the characteristics of the mycotoxicoses they can cause ICMSF [1].

Aflatoxins may contaminate many crops including corn, peanuts, cottonseed, Brazil nuts, pistachios, spices, copra (dried coconut), and figs with widespread contamination in hot and humid regions of the world. Human aflatoxicoses continue to be an occasional, serious problem. For example, a severe outbreak was reported in Kenya in 2002 CDC (2004). Half of the maize food samples tested in districts associated with this outbreak had Aflatoxins B1 levels $>20$ ppb. This outbreak had at least a 39\% incidence of death (317 cases with 125 deaths) resulting from acute hepatotoxicity [2].

The first line of defense against the introduction of aflatoxins is at the farm level and starts with implementation of Good
Agricultural Practices (GAP) to prevent infection. Preventive strategies should be implemented from pre- through postharvest. Preharvest strategies include maintenance of proper planting/ growing condition, antifungal chemical treatments and adequate insect and weed prevention. Postharvest measures include use of drying as dictated by moisture content of the harvested grain, appropriate storage conditions, and use of transport vehicles that are dry and free of visible fungal growth CAC (2003) [3]. While implementation of these precautions go a long way toward reducing aflatoxin contamination of foods, they alone do not solve the problem and should be an integral part of an integrated HACCPbased management system [4].

Wheat grains are often harvested at a moisture content which can allow the growth of molds and mycotoxin production. If the grains dried to safe moisture content (14-16\%), the fungal growth is delayed or inhibited and the toxin production will be inhibited too. Therefore temperature and humidity during wheat storage must be controlled during storage to maintain the grain healthy and prevent food poisoning. Therefore, different strategies have been developed to prevent fungal growth on food, one of which is supplementation with ozone gas [5]. Thus, the objective of the present work was to investigate the effectiveness of ozone as preservatives to control the fungal pollution in the imported wheat grains and to determine the effective dose which can be used as fungicide for wheat grains during storage. 


\section{Materials and Methods}

\section{Materials}

Five imported wheat grains (Triticum aestivum) different cultivars imported from Argentine, Germany, Ukrainian, Australia and U.S.A were obtained from five locations (Alexandria, Domiata, El-Suwas, El-Sokhna and Cairo) governorate and Egyptian wheat grains (Gemmiza 7) were obtained from El-Gharbia governorate. They were taken from six different Companies since 2009.

\section{Media and Reagents}

The following solutions and media were used for mold enumeration and identification: Peptone water, Rose Bengal chloramphenical agar (Biolife, Italy).

\section{Aflatoxins}

(B1, B2, G1 and G2) were obtained from Sigma chemical company (St. Louis, MO USA). Precoated TLC plates $(0.2 \mathrm{~mm}$ thick, 20x20 cm) coated with Silica gel/60, were obtained from Merck (Darmstadt, Germany).

\section{Methods}

Sampling and grain quality testing were carried out according to USDA [6]. Measurement of the temperature, moisture, air conduction and humidity in silos under investigation were carried out according to USDA [7]. Estimation of infested wheat was investigated according to USDA [8].

\section{Experiment}

a. Experiment 1: Physical and Chemical quality, grading, Determination of minerals and microbiology contamination of imported wheat before storing. Study quality of wheat grains by physical analyses such as grading, color and hardness and heavy metals contamination percentage and to determination of fulling number (FN), microbial load and Aflatoxin before storage

b. Experiment 2: Isolated fungal species, Mold count development, quality of imported wheat and aflatoxins production at the beginning of storage. Study microbial load contamination and it's count on wheat grains during storage for 90 days periodically weekly for 3 months at 250C room temperature to determined moisture content, protein content percentage, fat percentage, enzyme activity and aflatoxin after 21 days of the storage and also grading after 90 days of the storage.

c. Experiment 3: Determination of minerals, chemical quality of flour, isolated fungal species from imported wheat after storing 90 days and milling in some mills. Study the evaluation of the degree of contamination of the produced flour in some mills for import wheat grains in Egypt in order to estimate the effect of processing steps on the quality of final produced flour after 90 days of the storage at $25 c^{-0}$ room temperature by determination of microbial, heavy metals and aflatoxin contamination in flour.

Analytical Methods: Total mold count \& Fungal identification were carried out using Rose Bengal chloramphenical agar and incubated for 5-7 days at 250C. Fungal identification was performed for isolated fungi in Food Safety Lab, Regional Center for Food \& Feed, Agriculture Research Center and identified according to [9] Estimation of Aflatoxins content was determined using the method of A.O.A.C [10,11]. Moisture, current protein, lipids, current fiber and ash were determined the stander procedure described in AOAC method [12], the Nitrogen Free Extract (N.F.E) was calculated by difference. Minerals content ( $\mathrm{Mg}$, $\mathrm{Zn}, \mathrm{Mo}, \mathrm{Cr}, \mathrm{Cu}, \mathrm{Mn}, \mathrm{Se}, \mathrm{Hg}, \mathrm{Pb}, \mathrm{As}$, $\mathrm{Cd}, \mathrm{Li}, \mathrm{Ni}, \mathrm{Ba}$ ) were determined after aching of different samples according to A.O.A.C [10]. Maggerments were carrying out using Atomic absorption spectrophotometer model 3300 Perken for element. The data were calculated as mg metal / 100gm dry sample

\section{Results and Discussion}

\section{Quality of Six Different Wheat Kernels Before Storage}

Mean value of physical properties of six different wheat kernel cultivars are presented in (Table 1). Moisture content among all samples which was ranged from 8.6 to $9.8 \%$. the highest moisture content noticed for Australian stander white wheat while the lowest moisture content noticed for Egyptian soft white wheat (Gamaza7). It can be concluded that the test weight for all samples which ranged from 58.03 to 63.6 pound per bushel. The same trend was observed in test weight where Argentine soft red winter wheat the highest and followed by Australian stander white wheat, Germany hard red wheat, Egyptian soft white wheat, American soft red winter wheat and Ukrainian hard red wheat. More ever the foreign material among all samples ranged from 0.05 to $0.19 \%$, either Argentine soft red winter wheat has highest percentage of shrunken and broken kernels followed by Australian stander white wheat. For damage kernels which contest of heat damage and total damage, especially Argentine soft red winter wheat and Ukrainian hard red wheat which have highest total damage kernels percentage $(2.0 \%)$ while Egyptian soft white wheat (Gamaza7) have lowest percentage of total damage kernels (0.93\%). It can be noticed that the American soft red winter wheat, Australian stander white wheat and Egyptian soft white wheat haven't heat damage. More ever from the same table noticed that all sample are free from insect and ok odor. The Egyptian stander no. 1601/1986 and its modification on $23 / 4 / 2002$ has obligation that the dockage \% (first separated from sample) not exceed $1 \%$, foreign material $\%$ not exceed $1 \%$, total damage kernels \% (heat damage, sprout damage, insect damage and mould damage kernels) not exceed than $4 \%$. However, that difference between wheat samples, all wheat samples had grade one according to U.S department of agriculture, (2006 D). 
Table 1: Grading of six different wheat kernel cultivars.

\begin{tabular}{|c|c|c|c|c|c|c|c|}
\hline \multicolumn{2}{|c|}{ Wheat } & ArW & GeW & UkW & AmW & AuW & ESW \\
\hline \multicolumn{2}{|c|}{ M.C\% } & $9.0 \pm 0.5$ & $8.70 \pm 0.1$ & $9.40 \pm 0.1$ & $9.60 \pm 0.1$ & $9.80 \pm 0.07$ & $8.60 \pm 0.1$ \\
\hline \multicolumn{2}{|c|}{ T.W p/b } & $63.14 \pm 0.01$ & $61.95 \pm 0.01$ & $58.03 \pm 0.01$ & $60.30 \pm 0.1$ & $62.6 \pm 0.07$ & $61.55 \pm 0.01$ \\
\hline \multicolumn{2}{|c|}{ F.M\% } & $0.05 \pm 0.01$ & $0.16 \pm 0.01$ & $0.19 \pm 0.01$ & $0.13 \pm 0.01$ & $0.08 \pm 0.01$ & $0.10 \pm 0.01$ \\
\hline \multicolumn{2}{|c|}{ Sh.\& B.N\% } & $1.76 \pm 0.01$ & $0.72 \pm 0.01$ & $0.36 \pm 0.01$ & $0.52 \pm 0.01$ & $0.75 \pm 0.07$ & $0.48 \pm 0.01$ \\
\hline \multirow[t]{2}{*}{ D.K\% } & H.D & $0.10 \pm 0.1$ & $0.20 \pm 0.2$ & $0.10 \pm 0.7$ & Zero & Zero & Zero \\
\hline & T.D & $2.0 \pm 1.0$ & $1.50 \pm 0.1$ & $2.0 \pm 1.0$ & $1.60 \pm 0.1$ & $1.30 \pm 0.1$ & $0.93 \pm 0.01$ \\
\hline \multicolumn{2}{|c|}{ Odor } & $\mathrm{Ok}$ & Ok & $\mathrm{Ok}$ & $\mathrm{Ok}$ & $\mathrm{Ok}$ & $\mathrm{Ok}$ \\
\hline \multicolumn{2}{|c|}{ Insect } & Free & Free & Free & Free & Free & Free \\
\hline \multicolumn{2}{|c|}{ Grade } & 1 & 1 & 1 & 1 & 1 & 1 \\
\hline
\end{tabular}

Note: $T . W=$ Test weight, $\mathrm{p} / \mathrm{b}=$ Pound per Bushel (American unit), M.c = Moisture Content, F.M = Foreign Material, Sh. \& B.N = Shrunken \&Broken kernels, D.K = Damage Kernels, H.D = Heat Damage, T.D = Total Damage, ArW =Argentine Soft Red winter Wheat, GeW =Germany Soft Red Wheat, UkW =Ukrainian Hard Red Wheat, AmW =American Soft Red Winter Wheat, AuW =Australian Stander White Wheat, ESW=Egyptian soft White Wheat (gamaza 7).

Results in Table 2 showed that 1000 kernels wheat ranged from 33.5 to $45.2 \mathrm{gm}$. Argentine soft red winter wheat have highest value (45.2gm) while Ukrainian hard red wheat has lowest value(33.5gm). for addition the kernel colour in all samples are red wheat whereas Australian stander white wheat and Egyptian soft white wheat are white wheat. Additionally, it showed that wet, dry gluten, hydration ratio and gluten index ranged from (18.3 to $25.3 \%$ ), (8.1 to $12.7 \%$ ), (1.57 to $2.12 \%$ ) and (57.5 to $84.5 \%$ ) receptivity. From same table thesis results showed that the highest wet and dry gluten was observed in Australian stander white wheat (33.1\% and 12.7\%) whereas lowest value was observed in Egyptian soft white wheat

Table 2: Physical properties of six different wheat kernels.

\begin{tabular}{|c|c|c|c|c|c|c|}
\hline Wheat & ArW & GeW & UkW & AmW & AuW & ESW \\
\hline Weigh per 1000 kernels gm & $45.20 \pm 0.1$ & $39.50 \pm 0.1$ & $33.50 \pm 0.1$ & $33.60 \pm 0.1$ & $42.50 \pm 0.1$ & $34.80 \pm 0.1$ \\
\hline Hardness\% & $60 \pm 1.0$ & $57 \pm 1.0$ & $61 \pm 1.0$ & $65 \pm 1.0$ & $57 \pm 1.0$ & $63 \pm 1.0$ \\
\hline Colour & red & red & Red & red & white & White \\
\hline Wet gluten \% & $25.30 \pm 0.1$ & $27.80 \pm 0.1$ & $26.70 \pm 0.1$ & $23.70 \pm 0.1$ & $33.10 \pm 0.1$ & $18.30 \pm 0.1$ \\
\hline Dry gluten \% & $8.10 \pm 0.1$ & $10.80 \pm 0.1$ & $10.17 \pm 0.1$ & $10.10 \pm 0.1$ & $12.70 \pm 0.1$ & $4.42 \pm 0.1$ \\
\hline Hydration ratio & $212 \pm 0.1$ & $157 \pm 0.1$ & $162 \pm 0.1$ & $134 \pm 0.1$ & $160 \pm 0.1$ & $314 \pm 0.1$ \\
\hline Gluten index \% & $84.10 \pm 0.1$ & $59.70 \pm 0.1$ & $57.50 \pm 0.1$ & $95.50 \pm 0.1$ & $64.60 \pm 0.1$ & $70.50 \pm 0.1$ \\
\hline Falling Number sec & $427 \pm 1.0$ & $376 \pm 1.0$ & $442 \pm 1.0$ & $400 \pm 1.0$ & $445 \pm 1.0$ & $198 \pm 1.0$ \\
\hline
\end{tabular}

Note: ArW =Argentine Soft Red winter Wheat, GeW =Germany Soft Red Wheat, UkW =Ukrainian Hard Red Wheat, AmW =American Soft Red Winter Wheat, AuW =Australian Stander White Wheat, ESW=Egyptian soft White Wheat (gamaza 7).

\section{Macro, Micro and Heavy Metals for Six Different Wheat Kernels}

Data in Table 3 showed that macro, micro and heavy metals, it can be noticed that macro element ranged from (Mg) 281.3 to 470.8mg for all samples, where American soft red winter wheat had the highest Mg followed by Ukrainian hard red wheat, Egyptian soft white wheat Argentine soft red winter wheat, Australian stander white wheat, and Germany hard red wheat which have the lowest Mg. Additionally for micro element it can be noticed no have trend for micro element which range between highest and lowest for all micro element. More ever it can be observed some micro element
(Gamaza7) samples. On the other hand, American soft red winter wheat have highest gluten index moreover the other samples are different between that Australian stander white wheat and American soft red winter for the gluten properties. Falling which indicted enzyme activity of Alfa amylase. In case of falling number, Australian stander white wheat highest falling number (445 sec.) and lowest enzyme activity. From Table 2 it can be concluded that Australian stander white wheat have the good quality for physical properties in all different wheat samples followed by Argentine soft red winter wheat, American soft red winter wheat, Ukrainian hard red wheat and Germany hard red wheat. 
Table 3: Macro, Micro and Heavy metals for six different wheat kernels (wet basis).

\begin{tabular}{|c|c|c|c|c|c|c|c|}
\hline \multicolumn{2}{|c|}{ Wheat } & ArW & GeW & UkW & AmW & $\mathrm{AuW}$ & ESW \\
\hline Macro element mg & $\mathrm{Mg}$ & 307.7 & 281.3 & 443.2 & 470.8 & 286.8 & 403.1 \\
\hline \multirow{8}{*}{ Micro element Ppm } & $\mathrm{Zn}$ & 24.54 & 13.43 & 23.86 & 27.44 & 15.64 & 18.91 \\
\hline & Mo & 0.4 & 0.49 & 0.89 & 0.71 & 0.37 & 0.31 \\
\hline & Co & 0.07 & 0.07 & 0.02 & 0.11 & 0.11 & 0.19 \\
\hline & $\mathrm{Cr}$ & 1.49 & 0.41 & 0.56 & 0.63 & 0.58 & 0.74 \\
\hline & $\mathrm{Cu}$ & 4.57 & 2.53 & 4.39 & 4.45 & 2.26 & 3.79 \\
\hline & $\mathrm{Mn}$ & 40.81 & 21.16 & 35 & 50.53 & 27.58 & 31.29 \\
\hline & $\mathrm{Se}$ & 0.01 & 0.01 & 0.09 & 0.06 & 0.02 & 0.03 \\
\hline & Total & 71.89 & 38.09 & 64.81 & 83.93 & 46.56 & 50.54 \\
\hline \multirow{8}{*}{ Heavy metals Ppm } & $\mathrm{Hg}$ & 0.019 & 0.004 & 0.003 & 0.004 & 0.004 & 0.015 \\
\hline & $\mathrm{Pb}$ & 0.58 & 0.38 & 0.93 & 0.71 & 0.88 & 0.82 \\
\hline & As & 0.78 & 1 & 1.24 & 1.57 & 1.08 & 0.98 \\
\hline & $\mathrm{Cd}$ & 0.07 & 0.07 & 0.06 & 0.11 & 0.01 & 0.02 \\
\hline & $\mathrm{Li}$ & 0.74 & 0.97 & 2.21 & 2.35 & 1.74 & 0.63 \\
\hline & $\mathrm{Ni}$ & 0.49 & 0.33 & 0.45 & 0.9 & 0.53 & 0.55 \\
\hline & $\mathrm{Ba}$ & 8.37 & 3.47 & 4.58 & 9.25 & 3.86 & 3.6 \\
\hline & Total & 11.049 & 6.224 & 9.473 & 14.894 & 8.104 & 6.615 \\
\hline \multicolumn{2}{|c|}{ Total Micro element and heavy metals Ppm } & 82.939 & 44.314 & 74.283 & 98.824 & 54.664 & 61.875 \\
\hline
\end{tabular}

Note: ArW =Argentine Soft Red winter Wheat, GeW =Germany Soft Red Wheat, UkW Ukrainian Hard Red Wheat, AmW =American Soft Red Winter Wheat, AuW =Australian Stander White Wheat, ESW=Egyptian soft White Wheat (gamaza 7).

From (Table 3) it can be that total micro element and heavy material followed by American soft red winter wheat, Argentine soft red winter wheat, Ukrainian hard red wheat Egyptian soft white wheat ,Australian stander white wheat and Germany hard red wheat (98.824), (82.939), (74.283), (61.875), (54.664) and (44.314) receptivity. This Standard is applied to the grain of soft and durum wheat to be used for food and non-food purposes, and for export. Wheat division into types which represented indices, characteristics, and quality norms of wheat according to classes; obligatory requirements for wheat grain, which guarantee human, animal, and environmental safety and health (condition, odour, and colour of grain, infectiousness), (toxic elements, mycotoxins, and pesticides), (safety and industrial sanitation requirements) and (natural environment protection) approved by the Ministry of Health of Ukraine, [13]. No. 137. These results agree with result obtained by Nagarajan, [14].

\section{Aflatoxin Content for Six Different Wheat Kernels}

Results in Table 4 show that aflatoxin content in six different wheat kernels. It can be noticed that all samples had lowest aflatoxin content before storing under detection limit $(0.5 \mathrm{ppb})$ for aflatoxin, ochratoxin, zearalenone, fumonisin. More ever it can be concluded that all sample (Australian stander white wheat, Germany hard red wheat, Egyptian soft white wheat, American soft red winter wheat, Argentine soft red winter wheat and Ukrainian hard red wheat) under detection limit (0.5ppb) of the stander Egyptian maximum (B1=10ppb and total aflatoxin $=20 \mathrm{ppb}$ ). Aflatoxin content was valet within the safe limit $50 \mathrm{ml} / \mathrm{kg}$ recommended by FAO.

Table 4: Aflatoxin content for six different wheat kernels.

\begin{tabular}{|c|c|c|c|c|c|c|c|}
\hline \multicolumn{2}{|c|}{ Wheat } & ArW & GeW & UkW & AmW & AuW & ESW \\
\hline \multicolumn{2}{|c|}{ Ochratoxin ppb } & $*$ & $*$ & $*$ & $*$ & $*$ & $*$ \\
\hline \multicolumn{2}{|c|}{ Zearalenone ppb } & $*$ & $*$ & $*$ & $*$ & $*$ & $*$ \\
\hline \multicolumn{2}{|c|}{ Fumonisin ppb } & $*$ & $*$ & $*$ & * & $*$ & $*$ \\
\hline \multirow{5}{*}{ Aflatoxin ppb } & B1 & $*$ & $*$ & $*$ & $*$ & $*$ & $*$ \\
\hline & B2 & $*$ & $*$ & $*$ & $*$ & $*$ & $*$ \\
\hline & G1 & * & * & * & * & $*$ & * \\
\hline & $\mathrm{G} 2$ & $*$ & $*$ & $*$ & $*$ & $*$ & $*$ \\
\hline & Total & $*$ & * & $*$ & $*$ & $*$ & $*$ \\
\hline
\end{tabular}

Note: ${ }^{*}=$ Under detection limit $(0.50 \mathrm{ppb}), \mathrm{ArW}=$ Argentine Soft Red winter Wheat, GeW =Germany Soft Red Wheat, UkW Ukrainian Hard Red Wheat, AmW =American Soft Red Winter Wheat, AuW =Australian Stander White Wheat, ESW=Egyptian soft White Wheat (gamaza 7). 


\section{Isolated Fungal Species for Six Different Wheat Kernels}

Result of isolated fungal species for imported kernels (Australian stander white wheat, Germany hard red wheat, American soft red winter wheat, Argentine soft red winter wheat and Ukrainian hard red wheat) and Egyptian soft white wheat before storing are present in Table 5. Data show that total mould count ranged between 1.9 to $2.48 \mathrm{log} \mathrm{cfu} / \mathrm{g}$. Ukrainian hard red wheat had highest total mould count and Australian stander white wheat had lowest total mould count total mould count. Egyptian soft white wheat had total mould count between Australian stander white wheat and Ukrainian hard red wheat. From the same table, it can be noticed that isolated fungal species are different between all samples which some of isolated fungal species found in some samples and no found in other. Riba et al. [15] which reported that the dominant genus was Aspergillus, predominantly A. flavus, A. niger and A. versicolor. The other isolated species were A. ochraceus, A. alliaceus, A. carbonarius, A. terreus, A. fumigatus, A. candidus and Aspergillus spp. The occurrence and the levels of the genus Penicillium, Fusarium, Alternaria and Mucor were substantially lower than those of Aspergillus. The storage in silos shows high levels of Aspergillus (66 to 84\%), especially A. flavus, but A. niger and other fungi were isolated at relatively low percentages.

Table 5: Isolated fungal species for six different wheat kernels.

\begin{tabular}{|c|c|c|c|c|c|c|}
\hline \multirow{2}{*}{ Isolated Species } & \multicolumn{6}{|c|}{ Wheat } \\
\hline & ArW & GeW & UkW & AmW & AuW & ESW \\
\hline Mucor hiemalis & + & + & + & + & + & + \\
\hline Rhizopus oryzae & + & + & + & - & + & - \\
\hline Asp. candidus & + & - & + & - & - & - \\
\hline Asp. flavus & + & + & + & + & + & + \\
\hline Asp. ochraceus & + & - & + & - & - & + \\
\hline Asp. terrus & + & - & - & - & - & - \\
\hline Asp. ustus & + & - & - & - & - & - \\
\hline Fus. proliferatum & + & + & - & + & + & - \\
\hline Asp. niger & - & - & - & - & - & + \\
\hline Pen. citrinum & - & + & + & + & + & + \\
\hline Acremonium butyri & - & + & - & - & + & - \\
\hline Alternaria allesnara & - & + & - & - & - & - \\
\hline Asp. parasiticus & - & - & + & - & - & - \\
\hline $\begin{array}{l}\text { Cladosporium } \\
\text { macrocarpum }\end{array}$ & - & - & + & - & - & - \\
\hline Emericella nidulans & - & - & + & - & - & - \\
\hline Fus. oxysporum & - & - & - & + & - & - \\
\hline Pen. variale & - & - & - & + & - & - \\
\hline Total Mold count & \multirow{2}{*}{2.2} & \multirow{2}{*}{2} & \multirow{2}{*}{2.48} & \multirow{2}{*}{2.36} & \multirow{2}{*}{1.9} & \multirow{2}{*}{2.2} \\
\hline $\log \mathrm{cfu} / \mathrm{g}$ & & & & & & \\
\hline
\end{tabular}

Note: ArW =Argentine Soft Red winter Wheat, GeW =Germany Soft Red Wheat, UkW Ukrainian Hard Red Wheat, AmW =American Soft Red Winter Wheat, AuW =Australian Stander White Wheat, ESW=Egyptian soft White Wheat (gamaza 7).

Effect of Storage on Six Different Wheat Kernels After 90 days

Aflatoxins Content: Table 6 shows toxin production of aflatoxin determination (B1,B2,G1,G2 and total )after 90 days of storage at 250C were determined for five important wheat kernels (Australian stander white wheat, Germany hard red wheat, American soft red winter wheat, Argentine soft red winter wheat and Ukrainian hard red wheat) and Egyptian soft white wheat. All samples were under detection limit (0.5ppb) Egyptian soft white wheat, at zero time then increasing slowly all samples during the first 21 days, then it determined after 90 days and result show more increased in all samples which ranged between 2.5 and $12.6 \mathrm{ppb}$ for total aflatoxin and B1 ranged between 0.8 and 5.1ppb. the Ukrainian hard red wheat had highest value $12.6 \mathrm{ppb}$ for (total) and $5.1 \mathrm{ppb}$ for (B1) ,while the Argentine soft red winter wheat had the lowest value $2.5 \mathrm{ppb}$ for (total) and $0.8 \mathrm{ppb}$ for (B1). these results agreement with those Hussein et al. (2001) who reported that some molds are capable of producing more than one mycotoxin and some mycotoxins are produced by more than one fungal species. These results are agree with Antonia et al. [16,17] who reported that the wheat which is susceptible to these fungi infections through its growth, harvest, transport, and storage, is the most important staple food in Turkey. Therefore, this study has been undertaken to determine the AFB1, AFB2, AFG1, AFG2 levels by HPLC in forty-one wheat samples grown and consumed in some regions of Turkey. 
Table 6: Aflatoxins content for six different wheat kernels after 90 days of storage at $25^{\circ} \mathrm{C}$.

\begin{tabular}{|c|c|c|c|c|c|c|c|c|c|c|c|c|c|c|}
\hline \multirow[b]{2}{*}{ Wheat } & \multirow{2}{*}{ Aflatoxin ppb } & \multicolumn{13}{|c|}{ Storage period (days) } \\
\hline & & $\mathbf{0}$ & 7 & 14 & 21 & 30 & 36 & 42 & 49 & 60 & 66 & 72 & 84 & 90 \\
\hline \multirow{5}{*}{ ArW } & B1 & * & - & - & 0.5 & - & - & - & - & - & - & - & - & 0.8 \\
\hline & B2 & $*$ & - & - & 0.5 & - & - & - & - & - & - & - & - & 0.7 \\
\hline & G1 & $*$ & - & - & $*$ & - & - & - & - & - & - & - & - & 0.5 \\
\hline & G2 & * & - & - & * & - & - & - & - & - & - & - & - & 0.5 \\
\hline & Total & $*$ & - & - & 1.7 & - & - & - & - & - & - & - & - & 2.5 \\
\hline \multirow{5}{*}{ GeW } & B1 & $*$ & - & - & 1.3 & - & - & - & - & - & - & - & - & 4.2 \\
\hline & B2 & $*$ & - & - & 1 & - & - & - & - & - & - & - & - & 3.1 \\
\hline & G1 & $*$ & - & - & 1 & - & - & - & - & - & - & - & - & 2.1 \\
\hline & G2 & $*$ & - & - & 1 & - & - & - & - & - & - & - & - & 1.4 \\
\hline & Total & $*$ & - & - & 4.3 & - & - & - & - & - & - & - & - & 10.8 \\
\hline \multirow{5}{*}{ UkW } & B1 & $*$ & - & - & 1.6 & - & - & - & - & - & - & - & - & 5.1 \\
\hline & B2 & $*$ & - & - & 1.1 & - & - & - & - & - & - & - & - & 4 \\
\hline & G1 & $*$ & - & - & 1 & - & - & - & - & - & - & - & - & 2 \\
\hline & G2 & $*$ & - & - & 1 & - & - & - & - & - & - & - & - & 1.5 \\
\hline & Total & $*$ & - & - & 4.7 & - & - & - & - & - & - & - & - & 12.6 \\
\hline \multirow{5}{*}{$\mathrm{AmW}$} & B1 & * & - & - & 1 & - & - & - & - & - & - & - & - & 2.5 \\
\hline & B2 & $*$ & - & - & 0.7 & - & - & - & - & - & - & - & - & 2.1 \\
\hline & G1 & $*$ & - & - & 0.6 & - & - & - & - & - & - & - & - & 1.5 \\
\hline & G2 & $*$ & - & - & 0.7 & - & - & - & - & - & - & - & - & 1.3 \\
\hline & Total & $*$ & - & - & 3 & - & - & - & - & - & - & - & - & 7.4 \\
\hline \multirow{5}{*}{ AuW } & B1 & $*$ & - & - & 0.6 & - & - & - & - & - & - & - & - & 1.1 \\
\hline & B2 & * & - & - & $*$ & - & - & - & - & - & - & - & - & 0.6 \\
\hline & G1 & $*$ & - & - & 0.5 & - & - & - & - & - & - & - & - & 1 \\
\hline & G2 & $*$ & - & - & $*$ & - & - & - & - & - & - & - & - & 1.1 \\
\hline & Total & $*$ & - & - & 1.6 & - & - & - & - & - & - & - & - & 3.8 \\
\hline \multirow{5}{*}{ ESW } & B1 & * & - & - & 1.8 & - & - & - & - & - & - & - & - & 3.1 \\
\hline & B2 & $*$ & - & - & 0.6 & - & - & - & - & - & - & - & - & 2.5 \\
\hline & G1 & $*$ & - & - & 0.9 & - & - & - & - & - & - & - & - & 2.4 \\
\hline & G2 & $*$ & - & - & 0.7 & - & - & - & - & - & - & - & - & 1.1 \\
\hline & Total & $*$ & - & - & 4 & - & - & - & - & - & - & - & - & 9.1 \\
\hline
\end{tabular}

Note: $\left(^{*}\right)=$ Under detection limit $(0.5 \mathrm{ppb}),(-)=$ Not determined, ArW =Argentine Soft Red winter Wheat, GeW =Germany Soft Red Wheat, UkW Ukrainian Hard Red Wheat, AmW =American Soft Red Winter Wheat, AuW =Australian Stander White Wheat, ESW=Egyptian soft White Wheat (gamaza 7).

Mould Count Quality: (Table 7) illustrates the effect of storage on the mould development for six different wheat kernels during storage for 90 days at $250 \mathrm{C}$. In the beginning of the storage period Data showed that the total mould count ranged between 2.48 to $1.9 \log \mathrm{cfu} / \mathrm{g}$ and the highest total mould count was Ukrainian hard red wheat and the lowest Australian stander white wheat. after 21 days of storage at $250 \mathrm{C}$ total mould count decreased and ranged between 2.3 to $1.4 \mathrm{log} \mathrm{cfu} / \mathrm{g}$ for (Egyptian soft white wheat and Argentine soft red winter wheat) and (Australian stander white wheat) respectively. Generally there were increasing in total mould count by long time of the storage period for among of different wheat kernels so after 90 days it ranged between 4.0 to $3.0 \mathrm{log} \mathrm{cfu} / \mathrm{g}$ for (Argentine soft red winter wheat and Australian stander white wheat) to (Ukrainian hard red wheat and Germany hard red wheat). These results is agree with Reed et al. [18] who reported that the mold growth caused heating and aggregation was observed at higher temperatures when pellets remained moist, but the species of molds predominating were not those associated with the production of aflatoxin [19]. 
Table 7: Mould count quality for six different wheat kernels after 90 days of storage at $25^{\circ} \mathrm{C}$.

\begin{tabular}{|c|c|c|c|c|c|c|c|c|c|c|c|c|c|c|}
\hline \multirow{2}{*}{ Wheat } & \multirow{8}{*}{$\begin{array}{c}\text { Mold } \\
\text { count } \\
\text { log } \\
\text { cfu/g }\end{array}$} & \multicolumn{13}{|c|}{ Storage period (days) } \\
\hline & & 0 & 7 & 14 & 21 & 30 & 36 & 42 & 49 & 60 & 66 & 72 & 84 & 90 \\
\hline ArW & & 2.2 & 2.3 & 2.4 & 2.3 & 2.3 & 2.4 & 2.5 & 3 & 3 & 3 & 3.5 & 3.6 & 4 \\
\hline GeW & & 2 & 2 & 2.1 & 1.8 & 1.8 & 1.8 & 2.1 & 2.3 & 2.8 & 2.7 & 3 & 3 & 3 \\
\hline UkW & & 2.48 & 2.85 & 1.48 & 1.48 & 1.7 & 1.7 & 2 & 2.5 & 2.6 & 3 & 3 & 3.1 & 3 \\
\hline $\mathrm{AmW}$ & & 2.36 & 1.7 & 1.7 & 1.7 & 2 & 2.1 & 2.3 & 2.3 & 2.5 & 3 & 3 & 3.5 & 3.5 \\
\hline $\mathrm{AuW}$ & & 1.9 & 2.73 & 2 & 1.4 & 1 & 2.8 & 3 & 3 & 3 & 3.1 & 3.8 & 4 & 4 \\
\hline ESW & & 2.2 & 2.3 & 2.4 & 2.3 & 2.3 & 2.4 & 2.5 & 2.9 & 3 & 3 & 3 & 3.5 & 3.5 \\
\hline
\end{tabular}

Note: ArW =Argentine Soft Red winter Wheat, GeW =Germany Soft Red Wheat, UkW Ukrainian Hard Red Wheat, AmW =American Soft Red Winter Wheat, AuW =Australian Stander White Wheat, ESW=Egyptian soft White Wheat (gamaza 7).

Physical Properties: Comparison physical properties of six different wheat kernels before and after 90 days storage at 250C (Table 1) and (Table 8) result showed that all physical properties were increases test weight, foreign material, shrunken and broken kernels and damage kernels in all samples of wheat kernels after 90 days storage except the moisture content had redacted in all samples too [20]. the increase in all physical properties may be due to the redaction in the moisture content , it can be concluded that the increases in physical properties (foreign material and total damage) for Argentine Soft Red winter Wheat and Australian Stander White Wheat while Germany Soft Red Wheat increases in (Shrunken \& Broken kernels and total damage) which cause that redaction the grade of wheat kernels from grade (1) to grade (3). Moreover, the other wheat samples are sample grade [21].

Table 8: Physical properties of six different wheat kernels after 90 days storage at $25^{\circ} \mathrm{C}$.

\begin{tabular}{|c|c|c|c|c|c|c|c|}
\hline \multicolumn{2}{|c|}{ Wheat } & ArW & GeW & UkW & AmW & AuW & ESW \\
\hline \multicolumn{2}{|c|}{ М.c \% } & $8.10 \pm 0.1$ & $7.50 \pm 0.1$ & $8.40 \pm 0.1$ & $8.60 \pm 0.1$ & $8.80 \pm 0.1$ & $7.70 \pm 0.1$ \\
\hline \multicolumn{2}{|c|}{ T.W p/b } & $63.50 \pm 0.1$ & $62.30 \pm 0.1$ & $58.20 \pm 0.1$ & $60.70 \pm 0.1$ & $63.10 \pm 0.1$ & $62 \pm 1.0$ \\
\hline \multicolumn{2}{|c|}{ F.M\% } & $1.0 \pm 0.1$ & $0.70 \pm 0.1$ & $1.30 \pm 0.1$ & $1.0 \pm 0.5$ & $1.25 \pm 0.01$ & $0.50 \pm 0.1$ \\
\hline \multicolumn{2}{|c|}{ Sh.\& B.N\% } & $5.0 \pm 1.0$ & $8.0 \pm 1.0$ & $11.70 \pm 0.1$ & $6.50 \pm 0.1$ & $4.70 \pm 0.1$ & $4.40 \pm 0.1$ \\
\hline \multirow{2}{*}{ D.K\% } & H.D & $0.20 \pm 0.1$ & $0.50 \pm 0.1$ & $1.0 \pm 0.5$ & $0.40 \pm 0.1$ & $0.20 \pm 0.1$ & $0.10 \pm 0.1$ \\
\hline & T.D & $6.0 \pm 1.0$ & $5.30 \pm 0.1$ & $20.0 \pm 1.0$ & $8.0 \pm 1.0$ & $4.60 \pm 0.1$ & $3.70 \pm 0.1$ \\
\hline \multicolumn{2}{|c|}{ Odor } & ok & ok & musty & musty & ok & musty \\
\hline \multicolumn{2}{|c|}{ Insect } & Free & Free & Infested & Infested & Free & Infested \\
\hline \multicolumn{2}{|c|}{ Grade } & 3 & 3 & Sample grade & Sample grade & 3 & Sample grade \\
\hline
\end{tabular}

Note: $T . W=$ Test weight, $\mathrm{p} / \mathrm{b}=$ Pound per Bushel (American unit), M.c = Moisture Content, F.M = Foreign Material, Sh. \& B.N = Shrunken \&Broken kernels, D.K = Damage Kernels, H.D = Heat Damage, T.D = Total Damage, ArW =Argentine Soft Red winter Wheat, GeW =Germany Soft Red Wheat, UkW Ukrainian Hard Red Wheat, AmW =American Soft Red Winter Wheat, AuW =Australian Stander White Wheat, ESW=Egyptian soft White Wheat (gamaza 7).

\section{Chemical Composition}

(Figure 1) illustrates the effect of storage on the mould development for six different wheat kernels during storage for 90 days at 250C. In the beginning of the storage period Data showed that the total mould count ranged between 2.48 to $1.9 \mathrm{log} \mathrm{cfu} / \mathrm{g}$ and the highest total mould count was Ukrainian hard red wheat and the lowest Australian stander white wheat [22]. after 21 days of storage at 250C total mould count decreased and ranged between 2.3 to $1.4 \log \mathrm{cfu} / \mathrm{g}$ for (Egyptian soft white wheat and Argentine soft red winter wheat) and (Australian stander white wheat) respectively. Generally there were increasing in total mould count by long time of the storage period for among of different wheat kernels so after 90 days it ranged between 4.0 to $3.0 \mathrm{log} \mathrm{cfu} / \mathrm{g}$ for (Argentine soft red winter wheat and Australian stander white wheat) to (Ukrainian hard red wheat and Germany hard red wheat) [23].

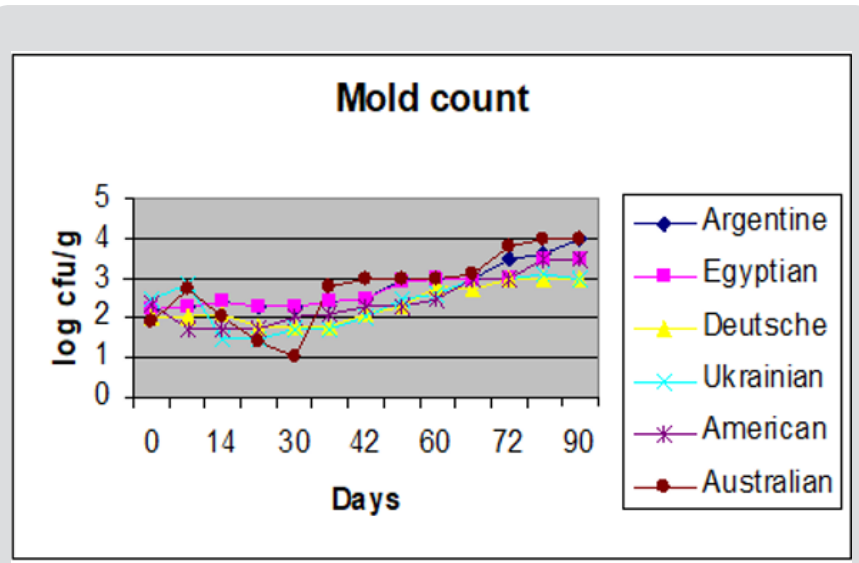

Figure 1: The mold development during storage for 90 days at $25^{\circ} \mathrm{C}$. 
Effect of Milling Processes for Six Different Wheat Kernels (wet basis) After Storing 90 Days:

Macro, Micro and Heavy Metals : (Table 9) showed that milling six different wheat kernels (wet basis) after storing 90 days to produce wheat flour of $72 \%$ extraction were reduced in metal pollution than the wheat metal, so the other parts produced from milling coarse bran, fine bran and semolina have highest percentage of metal pollution [24]. Data showed that metal pollution in all samples have arrange less than metal stander except $\mathrm{Cu}, \mathrm{Mn}$ and $\mathrm{Pb}$ which had highest range than the range of stander metal pollution in all samples with some highest in some wheat kernels metal stander [25]. The decreases of metal pollution due to the milling process cause to fibers from wheat kernels which is the most metal pollution found in the layer bran and aleurone of inner wheat kernels (Figures 2 \& 3) [26].

Table 9: Macro, Micro and Heavy metals for six different wheat kernels (wet basis) after storing 90 days and milling in some mills in Egypt during year 2009.

\begin{tabular}{|c|c|c|c|c|c|c|c|}
\hline \multicolumn{2}{|c|}{ Wheat } & ArW & GeW & UkW & AmW & AuW & ESW \\
\hline Macro element mg & $\mathrm{Mg}$ & 185.7 & 199.4 & 178.6 & 299.4 & 311.3 & 138.9 \\
\hline \multirow{8}{*}{ Micro element Ppm } & $\mathrm{Zn}$ & 11.83 & 9.6 & 9.61 & 11.32 & 15.66 & 7.18 \\
\hline & Mo & 0.17 & 0.12 & 0.28 & 0.57 & 0.35 & 0.16 \\
\hline & Co & 0.023 & 0.081 & 0.023 & 0.001 & 0.02 & 0.034 \\
\hline & $\mathrm{Cr}$ & 0.92 & 0.57 & 0.33 & 0.47 & 0.24 & 0.22 \\
\hline & $\mathrm{Cu}$ & 3.25 & 1.85 & 1.27 & 4.6 & 2.2 & 2.14 \\
\hline & $\mathrm{Mn}$ & 22.4 & 17.59 & 11.35 & 18.95 & 27.37 & 15.51 \\
\hline & Se & 0.002 & 0.012 & 0.003 & 0.003 & 0.001 & 0.001 \\
\hline & Total & 38.595 & 29.823 & 21.593 & 35.914 & 45.841 & 25.245 \\
\hline \multirow{8}{*}{ Heavy metals Ppm } & $\mathrm{Hg}$ & 0.024 & 0.018 & 0.018 & 0.008 & 0.006 & 0.006 \\
\hline & $\mathrm{Pb}$ & 0.69 & 0.92 & 0.92 & 1.05 & 0.83 & 0.98 \\
\hline & As & 0.23 & 0.57 & 0.57 & 0.64 & 0.7 & 0.4 \\
\hline & $\mathrm{Cd}$ & 0.011 & 0.002 & 0.023 & 0.011 & 0.048 & 0.002 \\
\hline & $\mathrm{Li}$ & 0.29 & 0.3 & 0.52 & 1.15 & 1.21 & 0.94 \\
\hline & $\mathrm{Ni}$ & 0.25 & 0.26 & 0.13 & 0.21 & 0.44 & 0.24 \\
\hline & $\mathrm{Ba}$ & 4.87 & 2.22 & 2.09 & 2.42 & 5.22 & 1.89 \\
\hline & Total & 6.365 & 4.29 & 4.271 & 5.489 & 8.454 & 4.512 \\
\hline \multicolumn{2}{|c|}{ Total Micro element and heavy metals Ppm } & 44.96 & 34.113 & 25.864 & 41.403 & 54.295 & 29.757 \\
\hline
\end{tabular}

Note: ArW =Argentine Soft Red winter Wheat, GeW =Germany Soft Red Wheat, UkW Ukrainian Hard Red Wheat, AmW =American Soft Red Winter Wheat, AuW =Australian Stander White Wheat, ESW=Egyptian soft White Wheat (gamaza 7).



Figure 2: The Enzyme activity of different wheat during storage for 90 days at $25^{\circ} \mathrm{C}$. 


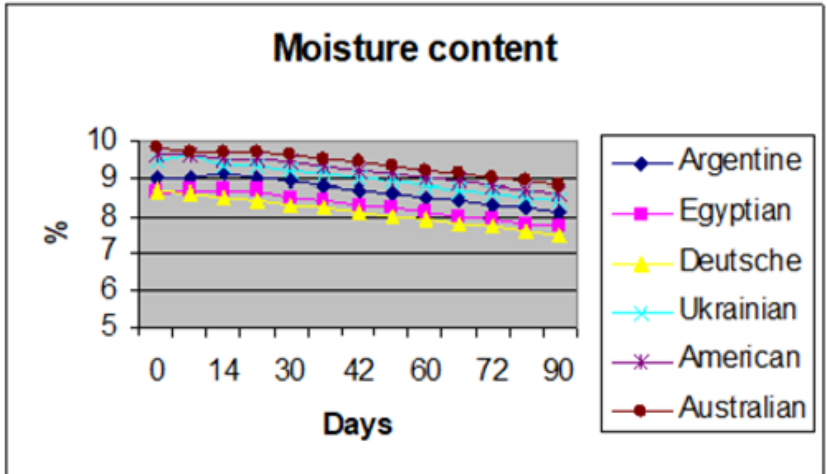

Figure 3: The Moisture content during storage for 90 days at $25^{\circ} \mathrm{C}$.

Isolated Fungal Species: Isolated fungal species from wheat flour mill (Australian stander white wheat, Germany hard red wheat, Egyptian soft white wheat, American soft red winter wheat, Argentine soft red winter wheat and Ukrainian hard red wheat) after storage 90 days presented that all among of samples are same isolated fungal species in (Table 5) but there are a new isolated fungal Asp. Niger at Argentine soft red winter wheat, Acremonium butyric at American soft red winter wheat and Ukrainian hard red wheat, Rhizopus oryzae at Egyptian soft white wheat, Emericella nidulans Australian stander white wheat. Data showed that all among of samples total count were between 3.2 to $5.0 \log \mathrm{cfu} / \mathrm{g}$ for the Argentine soft red winter wheat flour had the highest value $5.0 \log \mathrm{cfu} / \mathrm{g}$ while the Germany hard red wheat flour had lowest $3.2 \log \mathrm{fu} / \mathrm{g}$. so the results concluded that cylinders of milling are sources of increases fungal species pollution and total mould count because there are new isolated fungal species in some sample not found before and total mould count was increasing after milling than the total mould count had in (Table 10) [27]. These results are agreement with Weidenbörner et al. (2000) who reported that from milling showed no differences in the fungal contamination between the unclean wheat intended for milling and the clean wheat grain [28]. This may be explained by the contamination of the warehouse area by fungal spores and by the contact with contaminated equipment and machinery of the clean wheat (Figure 4).

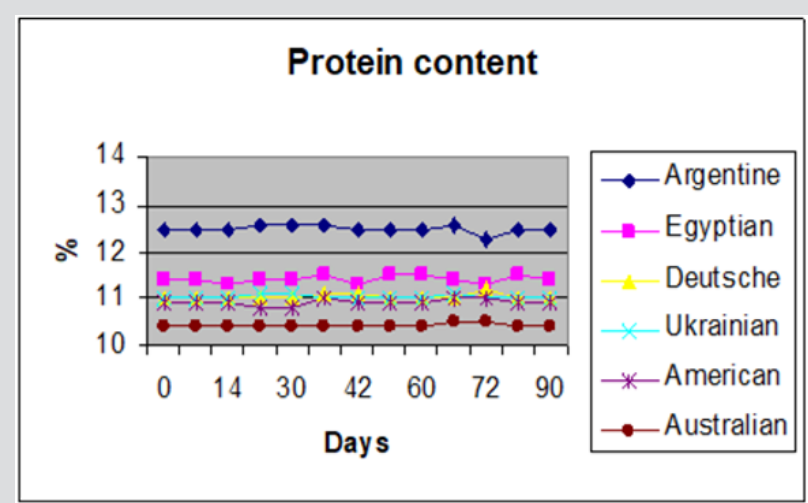

Figure 4: The Protein content during storage for 90 days at $25^{\circ} \mathrm{C}$.
Table 10: Isolated fungal species for six different wheat kernels after storing 90 days and milling in some mills in Egypt during year 2009.

\begin{tabular}{|c|c|c|c|c|c|c|}
\hline \multirow{2}{*}{ Isolated Species } & \multicolumn{6}{|c|}{ Wheat } \\
\hline & ArW & GeW & UkW & AmW & AuW & ESW \\
\hline Mucor hiemalis & + & + & + & + & + & + \\
\hline Rhizopus oryzae & + & + & + & - & + & + \\
\hline Asp. candidus & + & - & + & - & - & + \\
\hline Asp. Flavus & + & + & + & + & + & + \\
\hline Asp. ochraceus & + & - & + & - & - & + \\
\hline Asp. Terrus & + & - & - & - & - & - \\
\hline Asp. Ustus & + & - & - & - & - & - \\
\hline Fus. proliferatum & + & + & - & + & + & - \\
\hline Asp. Niger & + & - & - & - & - & + \\
\hline Pen. Citrinum & - & + & + & + & + & + \\
\hline Acremonium butyri & - & + & + & + & + & - \\
\hline Alternaria allesnara & - & + & - & - & - & - \\
\hline Asp. parasiticus & - & - & + & - & - & - \\
\hline $\begin{array}{l}\text { Cladosporium } \\
\text { macrocarpum }\end{array}$ & - & - & + & - & - & - \\
\hline Emericella nidulans & - & + & + & - & - & - \\
\hline Fus. oxysporum & - & - & - & + & - & - \\
\hline Pen. Variable & - & - & - & + & + & - \\
\hline Total Mold count & \multirow{2}{*}{5} & \multirow{2}{*}{3.2} & \multirow{2}{*}{3.5} & \multirow{2}{*}{3.8} & \multirow{2}{*}{4.6} & \multirow{2}{*}{4.1} \\
\hline $\log \mathrm{cfu} / \mathrm{g}$ & & & & & & \\
\hline
\end{tabular}

Note: ArW =Argentine Soft Red winter Wheat, GeW =Germany Soft Red Wheat, UkW Ukrainian Hard Red Wheat, AmW =American Soft Red Winter Wheat, AuW =Australian Stander White Wheat, ESW=Egyptian soft White Wheat (gamaza 7).

Aflatoxin Content: Data showed Table 11 that toxin production of aflatoxin determination (B1, B2, G1, G2 and total) after milling were increased that the results which determined after 90 days storage in Table (6) in all among of samples [29]. So, cylinders of milling are sources of increasing aflatoxin determination (B1, B2, G1, G2 and total) in all among of samples (Figure 5).

Table 11: Aflatoxin content of different wheat flour obtained from six different wheat kernels after milling in Egypt during year 2009

\begin{tabular}{|c|c|c|c|c|c|c|}
\hline \multicolumn{7}{|c|}{ Wheat Flour } \\
\hline Aflatoxin ppb & ArW & GeW & UkW & AmW & AuW & ESW \\
\hline B1 & 1.6 & 4.1 & 4.9 & 3 & 1.7 & 5.4 \\
\hline B2 & 1.3 & 2.9 & 3.1 & 2 & 1.5 & 2 \\
\hline G1 & 1 & 3.1 & 3 & 2 & 1 & 2.6 \\
\hline G2 & 1.1 & 2.9 & 3 & 2 & 1 & 2 \\
\hline Total & 5 & 13 & 14 & 9 & 5 & 12 \\
\hline
\end{tabular}

Note: ArW =Argentine Soft Red winter Wheat, GeW =Germany Soft Red Wheat, UkW Ukrainian Hard Red Wheat, AmW =American Soft Red Winter Wheat, AuW =Australian Stander White Wheat, ESW=Egyptian soft White Wheat (gamaza 7). 


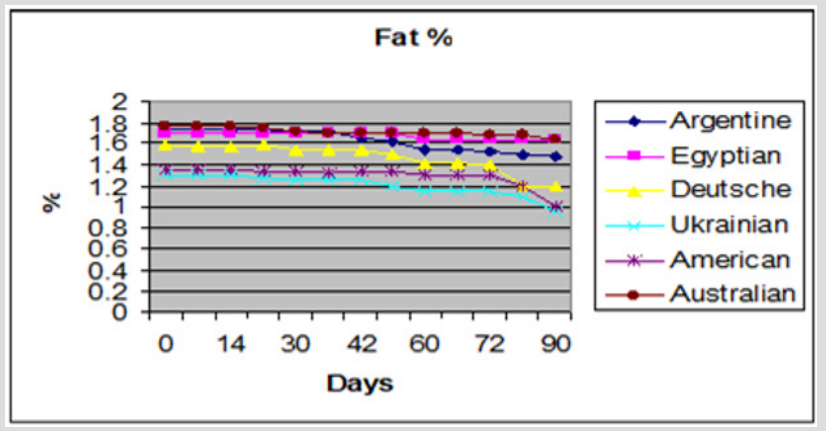

Figure 5: The Fat $\%$ during storage for 90 days at $25^{\circ} \mathrm{C}$.

\section{References}

1. Roberts TA, Baird-Parker AC, Tompkin RB (1996) Toxigenic fungi: Aspergillus. In: editors. Microorganisms in foods 5: microbiological specifications of food pathogens. International Commission on Microbiological Specifications for Foods. London, UK: Blackie Academic and Professional. An Imprint of Chapman \& Hall. pp. 347-381.

2. Gong YY, Cardwell K, Hounsa A, Turner PC, Hall AJ, et al. (2002) Dietary aflatoxin exposure and impaired growth in young children from Benin and Togo: Cross sectional study. BMJ 325: 20-1.

3. Qian GS, Ross RK, Yu MC, Yuan JM, Gao YT, et al. (2002) Mycotoxins Institute National de la Recherche Agronomique. Accessed 2006 Feb 10

4. Garcia LR, Park DL, Phillips TD (1999) Integrated mycotoxin management systems. Tunis, Tunisia: Third Joint FAO/WHO/UNEP International Conference on Mycotoxins. Document No.MYC-CONF/99/6a.

5. Watson W, Golding BT (1998) Weighing up the risks. Chem Britain 34: 45-48.

6. (1995) U.S. DEPARTMENT OF AGRICULTURE, Grain inspection handbook I. Grain Inspection, Packers and Stockyards Administration, Federal Grain Inspection Service Probe Sampling, Washington, D.C. 20090-6454.

7. (1999) U.S. Department of Agriculture, Moisture handbook Grain Inspection, Packers and Stockyards Administration 1400 Independence Ave., S. W. Washington, D.C. 20250-3600.

8. (2004) U.S. Department of Agriculture, Grain inspection handbook II Grain Inspection, Packers and Stockyards Administration, Federal Grain Inspection Service.

9. Samson RA, Hoekstra ES, Frisrad JC, Borg OF (1995) Introduction to Food Borne Fungal Handbook, Fourth edition.

10. (1990) Association of Official Analytical Chemists. Official Methods of Analysis. 15th Ed. Kenneth, H. ed. Published by A.O.A.C. Inc., Virginia, U.S.A.

11. (1995) Association of Official Analytical Chemists. Official Methods of Analysis. 16th Ed. Published by A.O.A.C. Benjamin Franklin station Washington, D.C, USA.

12. (2005) Association of Official Analytical Chemists. Official Methods of Analysis. 18th Ed. Published by A.O.A.C. W. Horwitz. North Frederick, U.S.A.
13. (2001) Ministry of Health of Ukraine. Instruction guidelines Procedure and frequency of alimentary raw materials and food products control according to safety indices, No. 137.

14. Nagarajan S (2005). Quality Characteristics of Indian Wheat. Quality and basic sciences 4: 79-86.

15. Riba S, Mokrane F, Mathieu A, Lebrihi A, Sabaou N (2008). Mycoflora and ochratoxin A producing strains of Aspergillus in Algerian wheat. International Journal of Food Microbiology 122: 85-92.

16. Frenich AG, Vidal JL M, Gonzalez RR, del Mar Aguilera-Luiz M (2009), Simple and high-throughput method for the multimycotoxin analyis in cereals and related foods by ultra-high performance liquid chromatography/tandem mass spectrometry. Food Chemistry 117: 705712 .

17. Giray B, Girgin G, Engin AB, Aydın S, Sahin G (2007) Aflatoxin levels in wheat samples consumed in some regions of Turkey. Food Control 18: 23-29.

18. Reed C, Stockli DT, Blasi DA, Fairchild FJ (2000) Storage of pelleted wheat middlings in farm bins. Animal Feed Science and Technology 88: 47-58.

19. Centers for Disease Control and Prevention (CDC) (2004) Outbreak of aflatoxin poisoning eastern and central provinces, Kenya, January-July. MMWR Morb Mortal Weekly Rep 53(34): 790-793.

20. FAO (2005) Food and Agriculture Organization. FAO Statistics Database. Accessed on: Feb14.

21. Hussein HS, Brasel JM (2001) Toxicity, metabolism, and impact of mycotoxins on humans and animals. Toxicology 167(2): 101-134.

22. Dejene M, Yuen J, Sigvald R (2004) Effects of storage methods, storage time and different agro-ecological zones on chemical components of stored sorghum grain in Hararghe, Ethiopia Journal of Stored Products Research 42: 445-456.

23. Pasha I (2006) Biochemical characterization of Pakistani wheats in relation to grain hardness. Ph.D. Thesis, Dept Food Technol Univ Agric Faisalabad.

24. Akhtar S, Anjum FM, Rehman SU, Sheikh MA, Farzana K, (2008) Effect of fortification on physico-chemical and microbiological stability of whole wheat flour. Food Chemistry 110: 113-119.

25. Samuels R, Modgil R (2003) Physico-chemical changes in insect infested wheat stored in different storage structures. Ind J Agric Sci 73: 562-563.

26. Samson RA, Hoekstra ES, Frisrad JC, Borg OF (1995) Introduction to Food Borne Fungal Handbook, Fourth edition.

27. (2002) U.S. Department of Agriculture, Equipment handbook. Grain Inspection, Packers and Stockyards Administration, S.W. Washington, D.C.

28. Weidenborner M, Wieczorek C, Appel S, Kunz B (2000) Whole wheat and white wheat flour-the mycobiota and potential mycotoxins. Food Microbiology 17: 103-107. 
ISSN: 2574-1241

DOI: 10.26717/BJSTR.2019.20.003461

El-Sisy Tt. Biomed J Sci \& Tech Res

(c) (P) This work is licensed under Creative

Submission Link: https://biomedres.us/submit-manuscript.php

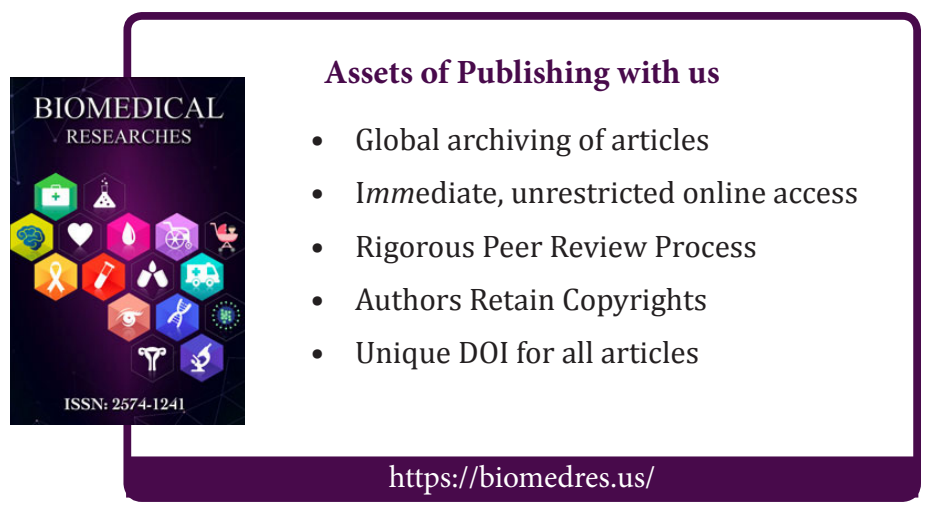

